\title{
Manajemen Praktikum Kepemimpinan Dan Renstra Berbasis Pengabdian Kepada Masyarakat
}

\author{
Novan Ardy Wiyani \\ IAIN Purwokerto \\ e-mail: fenomenajiwa@gmail.com
}

\begin{abstract}
ABSTRAK
Tujuan dari dilakukannya kegiatan ini adalah (1) memberikan media bagi mahasiswa untuk bisa mempraktikkan materi perkuliahan kepemimpinan; (2) membekali para siswa yang menjadi aktivis organisasi sekolah dengan berbagai keterampilan dalam memimpin dan mengelola organisasi. Untuk mencapai tujuan tersebut maka strategi yang penulis gunakan adalah dengan menjadikan mahasiswa sebagai tutor diklat kepemimpinan bagi siswa. Kegiatan dilaksanakan dalam empat tahapan. Pertama, tahap perencanaan kegiatan praktikum kepemimpinan dan renstra berbasis pengabdian kepada masyarakat. Kedua, tahap pengorganisasian kegiatan praktikum kepemimpinan dan renstra berbasis pengabdian kepada masyarakat. Ketiga, tahap pelaksanaan kegiatan praktikum kepemimpinan dan renstra berbasis pengabdian kepada masyarakat. Keempat, tahap pengawasan kegiatan praktikum kepemimpinan dan renstra berbasis pengabdian kepada masyarakat. Kegiatan ini dapat berlangsung optimal karena adanya dukungan dari stakeholders dan karena adanya jiwa kepemimpinan yang telah tertanam pada mahasiswa.
\end{abstract}

Kata Kunci: Diklat, Kepemimpinan, Mahasiswa, Praktikum, Siswa

\begin{abstract}
The objectives of this activity are (1) to provide media for students to be able to practice leadership lecture material; (2) equipping students who are activists in school organizations with various skills in leading and managing organizations. To achieve these objectives, the strategy I use is to make students as leadership training tutors for students. The activity was carried out in four stages. First, the stage of planning the practicum activities of leadership and community-based strategic planning. Second, the stage of organizing the activities of leadership practicum and community-based strategic planning. Third, the implementation phase of community service leadership and strategic planning activities. Fourth, the stage of supervision of community service practicum activities and strategic planning based on community service. This activity can take place optimally because of the support of stakeholders and because of the leadership that has been embedded in students.
\end{abstract}

Keywords: Education and training, Leadership, Students, Practicum, Students 


\section{PENDAHULUAN}

Pendidikan seringkali disebut sebagai bidang yang menentukan keberhasilan bangsa Indonesia dalam menyelenggarakan pembangunan nasional. Ini karena pendidikan dapat menghasilkan sumber daya manusia yang bermutu dan memiliki seperangkat kompetensi yang dibutuhkan untuk melakukan aktivitas pekerjaan baik dari sisi hard skills maupun dari sisi soft skills (Widiasworo, 2017). Namun sudah barang tentu pendidikan yang dapat menghasilkan sumber daya manusia yang demikian adalah pendidikan yang bermutu. Pendidikan yang bermutu bukan hanya bisa berkontribusi terhadap keberhasilan pembangunan nasional tetapi juga dapat membuat bangsa Indonesia mampu bersaing di kancah global (Widodo dkk., 2019). Itulah sebab pada dasarnya peningkatan mutu pendidikan adalah pilihan yang strategis di antara tuntutan persaingan global (Muhtifah \& Muskania, 2019).

Pendidikan yang bermutu dihasilkan oleh lembaga pendidikan yang bermutu. Betapa urgent-nya mutu dalam penyelenggaraan layanan pendidikan hingga akhirnya mutu dihadirkan dan menjadi target yang harus dicapai pada setiap jenjang pendidikan mulai dari jenjang pendidikan anak usia dini hingga jenjang pendidikan tinggi (Mulyasana, 2015). Dunia pendidikan pun saat ini telah intens melakukan berbagai perubahan dalam rangka meningkatkan mutu pendidikan (Rahmi, 2019).

Jenjang pendidikan tinggi melalui penyelengaraan layanan pendidikan yang bermutu dapat menghasilkan sumber daya manusia yang bermutu dan berdaya saing (Munadi dkk., 2019). Pada jenjang pendidikan tinggi, mutu harus ada pada kegiatan tri dharma perguruan tinggi, yaitu pendidikan dan pengajaran, penelitian, serta pengabdian kepada masyarakat (Khairiah \& Sirajuddin, 2019). Mutu pada tiga kegiatan tersebut dicapai secara beriringan agar ada keseimbangan dalam hal pencapaian mutu baik pada bidang pendidikan dan pengajaran, penelitian, maupun pengabdian kepada masyarakat (Prabowo, 2009). Tri dharma merupakan satu kesatuan integral yang memiliki hubungan satu sama lain. Keberadaan suatu kampus harus merepresentasikan tri dharma perguruan tinggi tanpa kecuali. Jadi, kampus bukan sekedar menjadi lembaga pendidikan, tapi juga menjadi lembaga penelitian, dan menjadi lembaga pengabdian pada masyarakat (Hikmah, 2014).

Untuk mendukung pelaksanaan kegiatan pendidikan dan pengajaran, kurikulum di perguruan tinggi didesain sesuai dengan standar KKNI (Kerangka Kualifikasi Nasional Indonesia). Kurikulum berbasis KKNI muncul sebagai respons dari Peraturan Presiden Nomor 8 Tahun 2012 (Maslahah, 2018). Kurikulum berbasis KKNI mendasarkan pengembangan dan penerapannya pada pencapaian kemampuan mahasiswa di perguruan tinggi yang telah disetarakan untuk menjaga mutu lulusannya (Muslih, 2018). 
Hal yang menarik dari penerapan kurikulum berbasis KKNI ini adalah mahasiswa diberi kesempatan yang luas untuk mempraktikkan berbagai materi perkuliahan yang didapatkannya (Susilo, 2018). Bahkan untuk mendukung hal tersebut, Fakultas Tarbiyah dan Ilmu Keguruan (FTIK) IAIN Purwokerto menyajikan mata kuliah praktikum untuk para mahasiswanya, salah satunya adalah mata kuliah praktikum kepemimpinan dan renstra yang diberikan kepada mahasiswa program studi Manajemen Pendidikan Islam (MPI). Mata kuliah tersebut memberikan kesempatan kepada para mahasiswa untuk mengasah jiwa kepemimpinannya. Penulis ditunjuk sebagai dosen pengampu pada mata kuliah praktikum tersebut.

Melihat desain kurikulum dan kondisi lapangan, maka penulis kemudian terdorong untuk menyelenggarakan perkuliahan praktikum kepemimpinan dan renstra berbasis pengabdian kepada masyarakat. Ada dua tujuan dari diadakannya perkuliahan praktikum kepemimpinan dan renstra berbasis pengabdian kepada masyarakat. Pertama, memberikan media bagi mahasiswa untuk bisa mempraktikkan materi perkuliahan kepemimpinan. Kedua, membekali para siswa yang menjadi aktivis organisasi sekolah dengan berbagai keterampilan dalam memimpin dan mengelola organisasi. Untuk mencapai tujuan tersebut maka strategi yang penulis gunakan adalah dengan menjadikan mahasiswa sebagai tutor diklat kepemimpinan bagi siswa.

Diakui ataupun tidak, materi-materi tentang kepemimpinan sangat dibutuhkan oleh generasi muda bangsa ini, termasuk para siswa, terutama materi-materi kepemimpinan yang menjadikan Pancasila sebagai core values-nya (Tanireja dan M. Yudhie Haryono, 2014). Diklat kepemimpinan bagi siswa diharapkan dapat dijadikan sebagai media untuk membentuk dan mengembangkan jiwa kepemimpinan pada siswa yang berkarakter. Kegiatan dan materi-materi diklat kepemimpinan yang diberikan kepada siswa dapat berkontribusi terhadap penanganan krisis kepemimpinan yang sedang dialami bangsa Indonesia saat ini (Sadiyah dkk., 2019).

\section{BAHAN DAN METODE}

Kegiatan pengabdian kepada masyarakat ini dilaksanakan secara terintegrasi dengan mata kuliah praktikum kepemimpinan dan renstra yang diampu oleh penulis dan diikuti oleh mahasiswa semester 6 program studi Manajemen Pendidikan Islam (MPI) FTIK IAIN Purwokerto. Penulis menggunakan pendekatan andragogi dalam pelaksanaan kegiatan ini, di mana mahasiswa dijadikan oleh penulis sebagai mitra dewasa dalam pelaksanaan kegiatan pengabdian kepada masyarakat.

Metode yang digunakan dalam kegiatan ini adalah metode diklat atau pendidikan dan pelatihan. Sedangkan strategi yang digunakan adalah dengan menjadikan mahasiswa sebagai tutor dalam diklat kepemimpinan bagi siswa yang akan dilaksanakan di sekolah maupun madrasah. 
Kemudian media yang digunakan dalam kegiatan ini antara lain kegiatan perkuliahan di dalam kelas dan di lapangan, WA Group, dan LCD Proyektor. Sedangkan bahan-bahan yang digunakan antara lain MoU antara FTIK IAIN Purwokerto dengan sekolah serta madrasah yang dituju, RPS yang disusun oleh penulis, materi perkuliahan kepemimpinan dan komunikasi organisasi serta TOR kegiatan dan laporan kegiatan yang disusun oleh mahasiswa.

\section{HASIL DAN PEMBAHASAN}

Kegiatan perkuliahan praktikum kepemimpinan dan renstra berbasis pengabdian masyarakat ini diselenggarakan melalui empat tahapan. Tahap pertama adalah perencanaan kegiatan praktikum kepemimpinan dan renstra berbasis pengabdian kepada masyarakat. Dalam konteks manajemen, perencanaan merupakan kegiatan yang pertama dan utama karena jalannya kegiatan manajemen yang lainnya akan dilaksanakan berdasarkan kegiatan perencanaan. Itulah sebab perencanaan menjadi fungsi yang paling utama dalam kegiatan manajemen (Muh.Hizbul Muflihin, 2015).

Pada tahap perencanaan ini penulis sebagai dosen pengampu mata kuliah praktikum kepemimpinan dan renstra membuat Rencana Pembelajaran Semesteran (RPS). RPS yang disusun berisi tentang identitas mata kuliah, identitas prodi, kelas, dan semester, capaian pembelajaran, kompetensi, indikator, materi, strategi dan media, serta evaluasi. RPS yang telah disusun kemudian disahkan oleh ketua jurusan Manajemen Pendidikan Islam (MPI) FTIK IAIN Purwokerto. RPS yang telah disahkan kemudian disampaikan pada mahasiswa di awal perkuliahan. Pada saat RPS disampaikan penulis memberikan deskripsi tentang kegiatan yang akan dilakukan oleh mahasiswa di dalam kelas dan di luar kelas atau di lapangan.

Kegiatan yang dilakukan di dalam kelas berbentuk kegiatan perkuliahan dengan materi konsep dasar kepemimpinan, strategi kepemimpinan tradisional dan modern, serta praktik kepemimpinan di lembaga pendidikan. Setelah itu mahasiswa diberi bekal materi penyusunan TOR (Term of References) kegiatan pengabdian masyarakat dengan tema utama "Kepemimpinan dalam Organisasi Pelajar di Sekolah". Selain itu mahasiswa juga diberi bekal materi penyusunan laporan kegiatan pengabdian kepada masyarakat dan penyusunan berita kegiatan pengabdian kepada masyarakat.

Berbagai materi yang diberikan oleh penulis kepada mahasiswa akan dijadikan bekal oleh mahasiswa untuk melaksanakan kegiatan di lapangan. Pada dasarnya kegiatan di lapangan inilah yang dijadikan sebagai sarana oleh penulis dan mahasiswa untuk melaksanakan kegiatan pengabdian kepada masyarakat. 
Dari 14 pertemuan, penulis sebagai dosen pengampu menyampaikan materi di dalam kelas sebanyak 7 pertemuan. Kemudian sisanya, 2 pertemuan untuk sosialisasi dan pembuatan TOR, 2 pertemuan untuk mengunjungi sekolah sebagai tempat pengabdian, 2 pertemuan untuk melaksanakan kegiatan pengabdian, dan 1 pertemuan untuk melaporkan hasil kegiatan pengabdian.

Pada dasarnya ada dua tujuan dari dilakukannya pengabdian kepada masyarakat melalui praktikum kepemimpinan dan renstra. Pertama, memberikan media bagi mahasiswa untuk bisa mempraktikkan materi perkuliahan kepemimpinan. Kedua, membekali para siswa di MTs/MA dan SMP/SMA/SMK yang menjadi aktivis organisasi sekolah dengan berbagai keterampilan dalam memimpin dan mengelola organisasi. Untuk mencapai tujuan tersebut maka strategi yang penulis gunakan adalah dengan menjadikan mahasiswa sebagai tutor diklat kepemimpinan untuk membekali para siswa di MTs/MA dan SMP/SMA/SMK. Dengan materi perkuliahan konsep dasar kepemimpinan, strategi kepemimpinan tradisional dan modern, serta praktik kepemimpinan di lembaga pendidikan diharapkan mahasiswa dapat menjadi tutor diklat yang baik dan kompeten bagi para siswa MTs/MA dan SMP/SMA/SMK.

Tahap kedua adalah pengorganisasian kegiatan praktikum kepemimpinan dan renstra berbasis pengabdian kepada masyarakat. Ada empat kegiatan yang dilakukan oleh penulis sebagai dosen pengampu mata kuliah praktikum kepemimpinan dan renstra.

Pertama, melakukan koordinasi dengan ketua jurusan MPI dan dekan FTIK bahwa penulis akan menerapkan model perkuliahan praktikum berbasis pengabdian kepada masyarakat. Ketua jurusan dan dekan FTIK begitu antusias mendengarkan penjelasan dari penulis. Ini karena hasil dari kegiatan pengabdian masyarakat bukan hanya bermanfaat untuk pihak internal kampus tetapi juga untuk pihak eksternal kampus, terutama dalam hal akreditasi program studi dan akreditasi sekolah.

Kedua, melakukan koordinasi dengan kepala bagian akademik FTIK untuk meminta data tentang MTs/MA dan SMP/SMA/SMK yang telah menjalin kerjasama dengan FTIK IAIN Purwokerto. Ketiga, melakukan koordinasi dengan wakil dekan III untuk memilih delapan sekolah atau madrasah yang dijadikan sebagai tempat kegiatan pengabdian kepada masyarakat. Delapan sekolah tersebut antara lain: (1) MTs al-Hidayah Karangsuci Purwokerto; (2) MTs al-Ittihad Ma'arif NU Purwokerto Barat; (3) MTs al-Masruriyah Kebumen Baturraden; (4) MTs Ma'arif NU 1 Kedungbanteng; (5) SMP Negeri 3 Purwokerto; (6) MA al-Ikhsan Beji Kedungbanteng; (7) SMA Diponegoro Purwokerto; dan (8) SMK Ma'arif NU Karanglewas. Ke semua sekolah dan madrasah tersebut berada di kabupaten Banyumas. Keempat, meminta pada staf FTIK copy 
Memorandum of Understanding (MoU) antara FTIK IAIN Purwokerto dengan delapan sekolah dan madrasah yang akan dituju untuk melaksanakan kegiatan pengabdian kepada masyarakat.

Pada dasarnya di dalam pengorganisasian dilakukan kegiatan koordinasi dengan setiap stakeholders, khususnya stakeholders yang menjadi pemangku kebijakan. Tujuannya bukan hanya untuk mendapatkan dukungan, tetapi agar mereka mau dan mampu untuk diajak bekerjasama oleh penulis dalam pelaksanaan kegiatan praktikum kepemimpinan dan renstra berbasis pengabdian kepada masyarakat (Wahjosumidjo, 2011). Pengorganisasian dapat dijadikan sebagai sebuah strategi untuk dapat melibatkan semua pihak dalam tingkat atau hierarki yang berbeda dari organisasi agar mampu bersama-sama meraih tujuan yang telah ditentukan (Efferi, 2019).

Tahap ketiga adalah pelaksanaan kegiatan praktikum kepemimpinan dan renstra berbasis pengabdian kepada masyarakat. Tahap ini merupakan tahap inti dari kegiatan praktikum kepemimpinan dan renstra berbasis pengabdian kepada masyarakat. Ada enam kegiatan yang dilakukan pada tahap ketiga. Pertama, sosialisasi tempat kegiatan pengabdian kepada masyarakat pada mahasiswa oleh penulis sebagai dosen pengampu. Ada dua kelas yang mengikuti kegiatan ini, yaitu kelas 6 MPI A sejumlah 40 mahasiswa dan kelas 6 MPI B sejumlah 46 mahasiswa. Masing-masing kelas kemudian dibagi menjadi 4 kelompok sehingga ada 8 kelompok, disesuaikan dengan jumlah sekolah dan madrasah yang hendak dituju. Hasil yang didapat dari kegiatan sosialisasi ini adalah adanya kesamaan frekuensi antara penulis sebagai dosen pengampu dengan para mahasiswa terkait dengan tujuan dari dilaksanakannya kegiatan praktikum kepemimpinan dan renstra berbasis pengabdian kepada masyarakat. Mahasiswa pun mendapatkan deskripsi yang jelas mengenai hal-hal apa saja yang harus dilakukan selama mengikuti kegiatan praktikum kepemimpinan dan renstra berbasis pengabdian kepada masyarakat.

Kedua, penyusunan TOR kegiatan pengabdian kepada masyarakat oleh mahasiswa. TOR tersebut berisi tentang rasionalisasi kegiatan, bentuk kegiatan, tujuan dan manfaat kegiatan, waktu dan tempat pelaksanaan, estimasi anggaran, kepanitiaan dan penutup. Penulis memberikan pendampingan kepada mahasiswa di luar jam perkuliahan dalam penyusunan TOR tersebut. Ini dilakukan agar TOR yang dibuat betul-betul bersifat operasional dan jelas untuk dipahami oleh semua pihak, khususnya oleh pihak eksternal. TOR disahkan oleh ketua kelompok, penulis sebagai dosen pengampu dan ketua jurusan MPI.

Ketiga, membuat dan menyampaikan surat permohonan praktikum kepada sekolah atau madrasah oleh mahasiswa. Surat permohonan tersebut berisi tentang permohonan untuk melaksanakan praktikum dalam bentuk pelatihan dasar kepemimpinan yang akan diikuti oleh para siswa pada sekolah dan madrasah yang dituju. Pada saat menyampaikan surat permohonan, mahasiswa juga memberikan dan mendeskripsikan TOR kegiatan serta melakukan perbincangan 
mengenai teknis pelaksanaanya. Berdasarkan hasil perbincangan tersebut didapatlah keputusan persetujuan mengenai waktu dan tempat yang diajukan oleh mahasiswa kepada pihak sekolah atau madrasah. Pada kegiatan ini mahasiswa diajarkan untuk melakukan komunikasi dengan pihak eksternal dalam konteks hubungan kelembagaan. Komunikasi tersebut berbentuk aktivitas melobi, melakukan negosiasi, dan mengambil keputusan (Somad dan Donni Juni Priansa, 2014). Kegiatan koordinasi antara mahasiswa dengan pihak sekolah atau madrasah juga dapat dijadikan sebagai media untuk mengasah kemampuan mahasiswa dalam memimpin (Machali, 2019).

Surat permohonan untuk melaksanakan kegiatan praktikum kepemimpinan dan renstra berbasis pengabdian kepada masyarakat ditandatangani oleh ketua jurusan MPI. Berikut adalah sampel gambar surat permohonan:

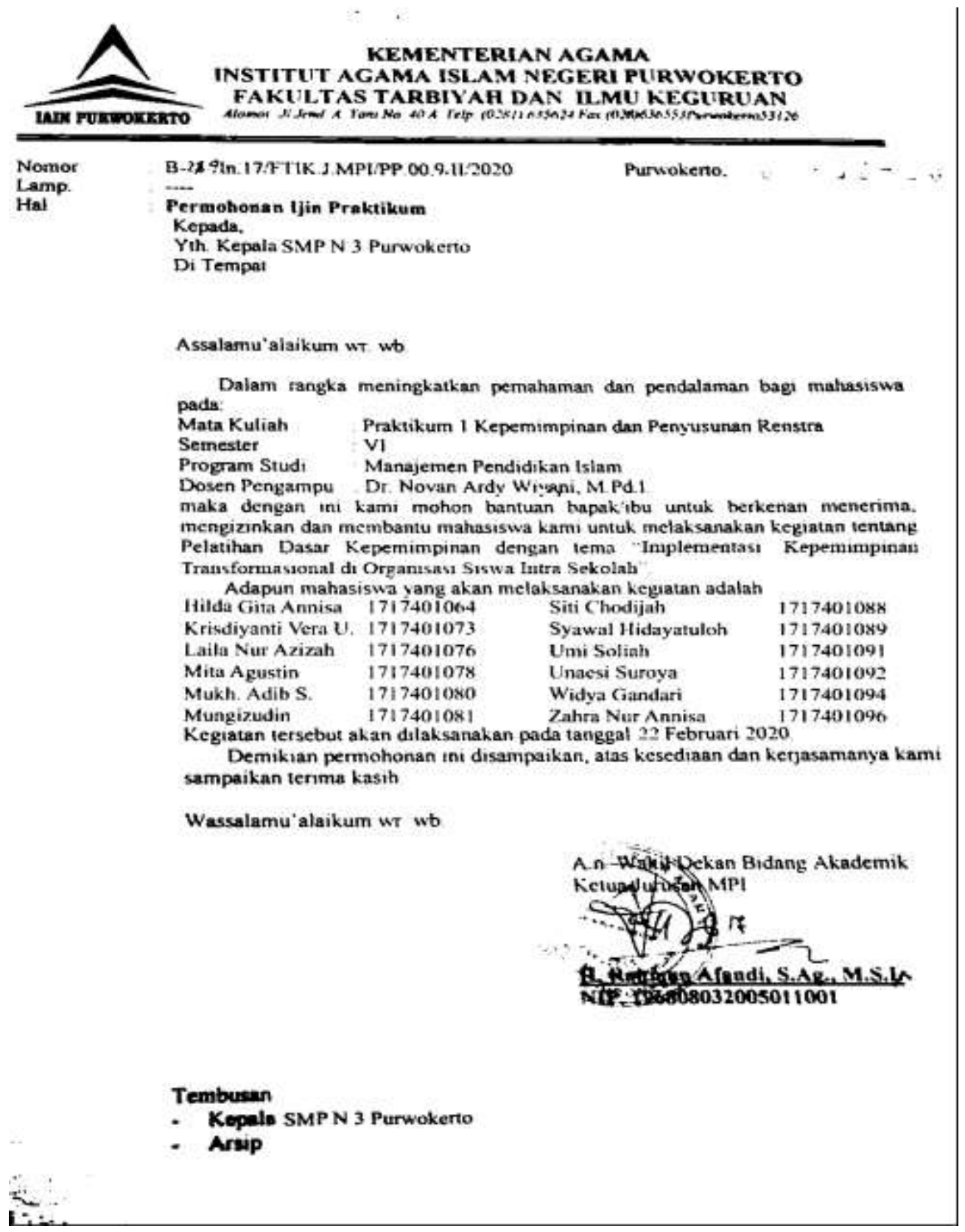

Gambar 1. Sampel Surat Permohonan 
Keempat, melaksanakan kegiatan pengabdian kepada masyarakat dalam bentuk diklat kepemimpinan bagi siswa di sekolah dan madrasah. Berikut adalah deskripsi pelaksanaan kegiatan pengabdian kepada masyarakat pada mata kuliah praktikum kepemimpinan:

1. MA al-Ihsan Beji Kedungbanteng

Kegiatan diklat dilaksanakan pada hari Sabtu, 29 Februari 2020. Kegiatan dimulai pada pukul 09.00. Kegiatan diikuti oleh 26 peserta. Pada sesi awal pemateri pertama, yaitu Adnan Muharrom menyampaikan materi perihal keorganisasian yang menjelaskan tentang pengertian organisasi, komponen atau struktur organisasi, dan fungsi organisasi, strategi dalam berorganisasi, dan kendala dalam berorganisasi di lingkungan sekolah.

Berikutnya pada sesi kedua pemateri Refa Mahdiyana menyampaikan materi tentang keberanian seorang pemimpin, bagaimana seorang pemimpin harus mempunyai jiwa mentalitas keberanian yang tinggi, keberanian merupakan sifat wajib yang harus dimiliki seorang pemimpin terutama keberanian dalam mengambil keputusan. Ada dua aspek kategori keberanian yaitu keberanian dalam bentuk fisik,dan keberanian dalam bentuk keyakinan. Keberanian fisik didapat dari latihan-latihan, ujian-ujian, serta benturan- benturan dan beberapa pengalaman. Sedangkan keberanian keyakinan berasal dari jiwa atau berasal dari diri sendiri yang dibawa sejak lahir dan memiliki mentalitas atau tekad yang kuat dalam menghadapi setiap realitas atau problematika kehidupan dari hal kecil sekalipun.

Kemudian sesi ketiga adalah sesi tanya jawab di mana moderator mempersilahkan para peserta untuk bertanya minimal 3 pertanyaan. Kemudian pada sesi terakhir dilakukan Focus Group Discution (FGD) untuk mempraktikan materi yang telah dipaparkan. Para peserta dibagi menjadi 3 grup untuk menyelesaikan masalah di dalam sebuah organisasi, setelah masalah bisa diselesaikan kemudian para peserta diwajibkan untuk memaparkan hasil diskusinya.

2. MTs al-Hidayah Karangsuci Purwokerto

Kegiatan diklat dilaksanakan pada hari minggu 22 Februari 2020. Peserta kegiatan berjumlah 19 peserta. Kegiatan diawali dengan acara pembukaan pada pukul 09.00 dan dibuka langsung oleh Bapak Maful Sugianto, S.Ag selaku Pembina OSIS MTs al-Hidayah Karangsuci Purwokerto. Kemudian dilanjutkan acara seminar dengan Narasumber I Anjar Wahyu Adi menyampaikan materi tentang Kepemimpinan, dan Narasumber II Nia Nur Pratiwi dengan materi tentang Keorganisasian.

Acara seminar yang bertempat di Auditorium MTs al-Hidayah tersebut berlangsung sangat menarik, tak jarang kedua narasumber membuat Ice Breaking yang mampu menarik perhatian peserta diklat. Narasumber juga membuka sesi tanya jawab dengan peserta agar 
peserta lebih memahami bukan hanya teori tetapi praktiknya dalam kehidupan berorganisasi. Dengan adanya seminar ini diharapkan peserta diklat sebagai anggota OSIS dapat menjadi organisator yang mampu membawa OSIS MTs al-Hidayah lebih aktif lagi dari sebelumnya dan sebagai bekal menjadi pemimpin di masa depan.

Kemudian acara dilanjut dengan kegiatan outbond dengan para anggota OSIS di Lapangan MTs al-Hidayah dari pukul 13.00 sampai dengan pukul 16:00 yang diisi dengan 5 permainan berupa estafet air, meniti bambu, memasukan paku dalam botol, kemampuan indra manusia, dan dos-dosan. Para peserta diklat sangat menikmati kegiatan outbond ini. Banyak keseruan yang tercipta melalui permainan-permainan yang ada. Kegiatan outbond tersebut sekaligus menjadi akhir dari rangkaian acara diklat di MTs al-Hidayah Karangsuci Purwokerto.

Secara keseluruhan, acara dapat berjalan dengan baik. Ada beberapa faktor pendukung yang mempengaruhi keberhasilan kegiatan diklat ini, yaitu (1) Dosen pembimbing yang memberikan arahan dengan baik dalam pelaksanaan sebelum serta ketika diklat berlangsung; (2) Sarana dan prasarana yang mencukupi; (3) Hubungan dengan pihak sekolah yang baik; (4) Kerjasama antara mahasiswa dengan anggota pengurus OSIS yang baik; (5) Akses mudah dari IAIN Purwokerto ke MTs al-Hidayah Karangsuci Purwokerto.

Meskipun secara keseluruhan acara berjalan dengan baik, ada beberapa faktor penghambat yang mempengaruhi jalannya kegiatan diklat di MTs al-Hidayah Karangsuci Purwokerto, yaitu (1) Keterbatasan waktu pelaksanaan sehingga tidak bisa menyusun rencana strategi yang lebih baik. (2) Peserta diklat yang terlalu sedikit. (3) Pendanaan yang tidak disubsidi sehingga mahasiswa mengeluarkan biaya yg besar untuk pelaksanaan praktikum.

3. MTs al-Ittihad Ma'arif NU Purwokerto Barat

Kegiatan diklat dilaksanakan pada hari minggu, 29 Februari 2020 bertempat di MTs alIttihad Ma'arif NU 1 Purwokerto Barat yang dimulai pada pukul 08.00 sampai dengan 15.00 WIB. Peserta kegiatan berjumlah 50 siswa. Hasil yang diperoleh dari kegiatan di MTs alIttihad Ma'arif NU Purwokerto Barat adalah pengalaman dan pembelajaran mengenai kepemimpinan, organisasi dan situasi organisasi madrasah di MTs al-Ittihad Ma'arif NU Purwokerto Barat.

Pada semester 3 mahasiswa sudah memperoleh mata kuliah kepemimpinan dan pada semester 4 ada mata kuliah komunikasi organisasi, sehingga pada saat pelaksanaan kegiatan dapat memberikan materi yang baik dan dapat menyampaikannya kepada peserta.

Faktor pendukung dari kegiatan ini adalah adanya bimbingan dan arahan yang diberikan oleh dosen pembimbing baik sebelum terjun di lapangan maupun ketika terjun ke lapangan 
untuk melakukan pendampingan. Faktor pendukung lainnya adalah adanya kerjasama dan komunikasi yang baik antara dosen, mahasiswa, dan pihak sekolah. Faktor yang menghambat pelaksanakan kegiatan ini adalah kendala teknis pada saat kegiatan dan waktu yang mulur sehingga harus mencari strategi lain agar semua kegiatan dapat berjalan sebagai mana mestinya.

4. MTs Ma'arif NU Kedungbanteng

Kegiatan diklat kepemimpinan di MTs Ma'arif NU Kedungbanteng dilaksanakan pada hari sabtu 29 Februari 2020 di MTs Maarif NU 1 Kedungbanteng. Kegiatan dimulai pada pukul 07.30 di gedung IPHI di mana ruangan tersebut berada di dalam MTs Maarif NU 1 Kedungbanteng. Kegiatan dihadiri oleh siswa-siswi MTs Maarif NU 1 Kedungbanteng yang merupakan perwakilan peserta didik dari kelas 7-8 A,B, dan C beserta anggota organisasi khusunya OSIS.

Pada pukul 07.30 kegiatan dimulai dengan pengisian daftar hadir yang disediakan panitia di depan pintu ruangan. Para siswa yang mengikuti kegiatan mengisi daftar hadir tersebut kemudian masuk ke ruangan untuk mengikuti kegiatan selanjutnya.

Penyampaian materi diklat disampaikan oleh mahasiswa dengan melakukan tanya jawab serta diskusi kelompok. Semua peserta mengikuti kegiatan dengan tertib sesuai dengan persyaratan yang telah ditentukan oleh mahasiswa. Peserta juga sangat antusias dan aktif pada setiap sesi kegiatan. Pihak MTS Maarif NU 1 Kedungbanteng sangat mensupport dan memberikan kebebasan kepada mahasiswa untuk melaksanakan kegiatan diklat.

Untuk mengurangi kejenuhan para peserta, panitia memberikan beberapa ice breaking yang dimaksudkan supaya para peserta tidak merasa bosan dan tetap fokus pada acara yang sedang berlangsung. Pada akhir acara dilakuakn praktik training dan games, di mana games tersebut merupakan pengimplementasian dari materi kepemimpinan.

Pelaksanaan games terkendala oleh masih adanya peserta yang tidak membawa perlengkapan dan terkendala juga oleh cuaca yang kurang mendukung, di mana games yang seharusnya dilaksanakan di luar ruangan, terpaksa ada beberapa games yang dilaksanakan di dalam ruangan karena hujan. Namun, di luar itu semua, kegiatan berjalan dengan lancar dan sejalan dengan apa yang sudah mahasiswa persiapkan.

\section{SMA Diponegoro Purwokerto}

Kegiatan diklat kepemimpinan di SMA Diponegoro Purwokerto dilaksanakan pada hari sabtu tanggal 14 Maret 2020. Kegiatan diklat kepemimpinan dilaksanakan dari mulai jam 08.00 saampai dengan 14.00. Peserta kegiatan diklat berjumlah 28 siswa. 
Kegiatan diklat diawali dengan pemberian boks yang di dalamnya terdapat pertanyaan dan kuis yang berhubungan dengan kepemimpinan. Siswa diminta untuk mengambilnya kemudian dipersilahkan untuk menjawab setiap pertanyaan. Kegiatan ini dilakukan sebagai salah satu bentuk pre-test bagi peserta diklat kepemimpinan.

Kemudian dilanjutkan dengan penyampaian materi. Materi yang disajikan mendeskripsikan tentang beberapa cara agar bisa memimpin organisasi, lembaga, dan diri sendiri. Materi lainnya yaitu tentang keorganisasian dan materi tentang administrasi seperti pembuatan surat-menyurat baik dari mulai kop surat sampai dengan tanda tangan serta melipat surat.

Setelah penyampaian materi, peserta melaksanakan outbound di kawasan atau lingkungan SMA Diponegoro yang mana dalam outbound tersebut dibagi menjadi 3 pos. Pos yang pertama tentang kepemimpinan, pos yang kedua tentang keorganisasian dan pos yang ketiga tentang keadministrasian. Di dalam pelaksanaan outbound bukan hanya materi diberikan dalam bentuk praktik memimpin.

6. SMK Ma'arif NU Karanglewas

Kegiatan diklat kepemimpinan di SMK Ma'arif NU Karanglewas dilaksanakan pada sabtu 22 Februari 2020. Peserta kegiatan berjumlah 28 siswa. Pada kegiatan diklat kepemimpinan diberikan 2 materi pokok, yaitu tentang kepemimpinan dan tentang administrasi.

Materi tentang kepemimpinan mengkaji tentang konsep kepemimpinan, gaya kepemimpinan dan praktik kepemimpinan. Sedangkan materi tentang administrasi menyajikan tentang tata persuratan dan pembuatan proposal kegiatan sekolah serta desa.

Faktor pendukung dalam pelaksanaan diklat kepemimpinan ini antara lain: (1) Tempat dan fasilitas diklat yang memadai, di mana diklat dilaksanakan di aula sekolah dilengkapi sound system, LCD Proyektor, meja dan kursi administrasi. (2) Waktu pelaksanaan diklat yang cukup dan diklat berjalan sesuai rencana. (3) Peserta diklat yang sangat antusias mendengarkan dan menanggapi pemateri dengan aktif bertanya pada setiap penyampaian materi.

7. SMP Negeri 3 Purwokerto

Kegiatan diklat kepemimpinan di SMP Negeri 3 Purwokerto dilaksanakan pada sabtu tanggal 22 Februari 2020. Kegiatan diikuti oleh 35 peserta didik dari pengurus OSIS. Penyampaian materi dilaksanakan mulai pukul 08.30 WIB di Aula SMP Negeri 3 Purwokerto.

Terdapat 2 materi yang dipaparkan yaitu materi kepemimpinan secara umum oleh Siti Chodijah dan materi kepemimpinan transformasional oleh Muh. Adib Shofawi. Keduanya 
diberi waktu 15 menit untuk masing-masing materi. Penyampaian materi diikuti oleh seluruh pengurus OSIS. Pemateri juga membuka kesempatan yang bertanya kepada peserta tentang materi yang disampaikan.

Pemateri pertama memulai dengan sambutan semangat kepada peserta setelah diantarkan oleh moderator. Pemateri kedua memulai dengan ice breaking yang diikuti para siswa dengan semangat. Para pembina juga terlihat antusias dalam mengawasi penyampaian materi. Pada sesi tanya jawab, para peserta mampu bertanya, berdiskusi dan berinteraksi dengan baik. Penyampaian materi diakhiri dengan ice breaking.

Setelah rangkaian kegiatan penyampaian materi berakhir, rangkaian kegiatan terakhir, yaitu problem solving. Penanggung jawab dalam praktik ini menjelaskan terlebih dahulu bagaiamana teknis pelaksanaan problem solving, di mana kegiatan ini dilakukan di luar kelas atau halaman sekolah. Pengurus OSIS SMP Negeri 3 Purwokerto kemudian dibagi menjadi enam kelompok, setiap kelompok didampingi oleh masing-masing pendamping yakni dipilih dari panitia pelaksanaan praktikum kepemimpinan tersebut, setiap kelompok berjumlah kurang lebih 5 sampai 6 siswa. Setiap kelompok diberikan contoh persoalan dan diarahkan oleh pendampingnya kemudian siswa membahas persoalan tersebut dan didiskusikan yang pada tujuannya untuk menemukan titik temu atau solusi dari persoalan tersebut yang nantinya akan dipresentasikan oleh perwakilan dari setiap kelompok di depan forum.

Presentasi oleh masing-masing kelompok dilanjut dengan tanya jawab atau diskusi besar, dengan tujuan agar semua siswa dari kelompok diberikan kesempatan untuk berbicara dan saling tukar pendapat dan saling menanggapi dengan bergantian. Kemudian dari mahasiswa memberikan point atau nilai untuk kelompok yang aktif dalam diskusi, yang nanti pada closing mendapatkan dorprize. Setelah semua kelompok diskusi dan presentasi, untuk penutup dari diskusi dari mahasiswa memberikan sedikit materi atau kesimpulan dari diskusi bersama. Dalam kegiatan ini tentunya siswa dilatih untuk berfikir memecahkan permasalahan dan mencari solusi baik itu dalam ranah sosial maupun pendidikan, yang jelas siswa menjadi lebih luas wawasan serta belajar menjadi pemimpin yang berani dan bertanggungjawab serta cekatan.

Adapun beberapa siswa yang masih pasif dan memilih diam tetapi tetap dalam kondisi memperhatikan diskusi, itu berarti belum sepenuhnya semua siswa mampu mengikuti kegiatan ini dengan khidmat, yang artinya mahasiswa praktikum kurang mampu memahami setiap karakter siswa karena waktunya juga yang belum memungkinkan agar panitia kurang dalam pendekatan emosionalnya dan pendekatan sosialnya. Kemudian setelah kegiatan diskusi, dilanjut dengan pencairan suasana, yaitu beberapa games. 
Faktor yang mendukung pelaksanaan kegiatan ini adalah semua peserta terlihat sangat antusias dan memperhatikan dengan baik apa yang disampaikan oleh pemateri sehingga acara berjalan dengan lancar. Faktor penghambatnya adalah faktor cuaca yang panas sehingga konsentrasi peserta mudah terganggu.

8. MTs al-Masruriyah Kebumen Baturraden

Kegiatan diklat kepemimpinan di MTs al-Masruriyah Kebumen Baturraden dilaksanakan pada minggu 23 Februari 2020. Kegiatan diikuti oleh 30 Pengurus OSIS MTs al-Masruriyah dengan rincian putra 11 siswa dan putri 19 siswi.

Acara dimulai sekitar pukul 08.00 pagi. Pembina OSIS, Waka kesiswaan, dan dosen pembimbing turut menghadiri acara pembukaan. Kemudian acara dilanjutkan dengan pembekalan materi seputar organisasi yakni meliputi materi kepemimpinan, komunikasi organisasi, dan administrasi organisasi. Setelah materi selesai, acara dilanjut dengan kegiatan diskusi kelompok guna mereview ulang materi dalam kelompok kecil. Dalam sesi diskusi ini, peserta ditemani langsung pendamping yang akan memantik peserta untuk lebih aktif menyampaikan gagasan yang telah didapat dari materi sebelumnya.

Setelah diskusi kelompok, acara dilanjutkan adalah kegiatan outbound yang berisi ice breaking dan energizer yang memuat nilai nilai kepemimpinan. Suasana pecah seketika ketika musik tiba-tiba dimainkan, semua peserta pun berjoget dengan riang gembira. Momen ini memang sengaja dimasukan, agar peserta tidak merasa jenuh dan lelah. Kegiatan outbound dilaksanakan setelah ishoma, di mana per kelompok bergantian untuk melaksanakan outbound. Kegiatan ini berlangsung sangat hangat dan penuh kekompakan, penuh keceriaan, dan keakraban. Ada 3 pos outbound yang harus diselesaikan seluruh kelompok.

Kegiatan ditutup sekitar pukul 16.00 WIB oleh pembina OSIS dan dilanjutkan dengan mushofahah bersama. Faktor pendukung dalam kegiatan diklat kepemimpinan ini antara lain (1) pihak madrasah memberikan kebebasan sepenuhnya kepada mahasiswa dalam pelaksanaan kegiatan; (2) kedisiplinan dan antusiasme para peserta; dan (3) kekompakan tim dalam mengikuti acara. Sedangkan faktor penghambatnya yaitu: (1) jumlah peserta tidak sesuai dengan kuota yang diharapkan; (2) beberapa peserta tidak membawa alat tulis dan barang bawaan yang telah ditetapkan oleh mahasiswa; (3) peserta kurang kondusif pada saat pemberian materi dan pengarahan dari panitia; (4) kapasitas ruangan yang kurang memadai.

Kelima, menyusun teks berita kegiatan pelaksanaan diklat. Teks berita kegiatan pelaksanaan diklat ditulis oleh mahasiswa di bawah bimbingan penulis sebagai dosen pengampu mata kuliah praktikum kepemimpinan dan renstra. Teks berita yang telah dibuat kemudian direview oleh penulis. Berdasarkan hasil review kemudian mahasiswa melakukan 
perbaikan terhadap teks berita. Teks berita yang telah diperbaiki kemudian dipublikasikan pada website FTIK IAIN Purwokerto dengan alamat http://ftik.iainpurwokerto.ac.id/.

Berikut adalah sampel berita kegiatan yang telah dipublikasikan pada website FTIK IAIN Purwokerto:

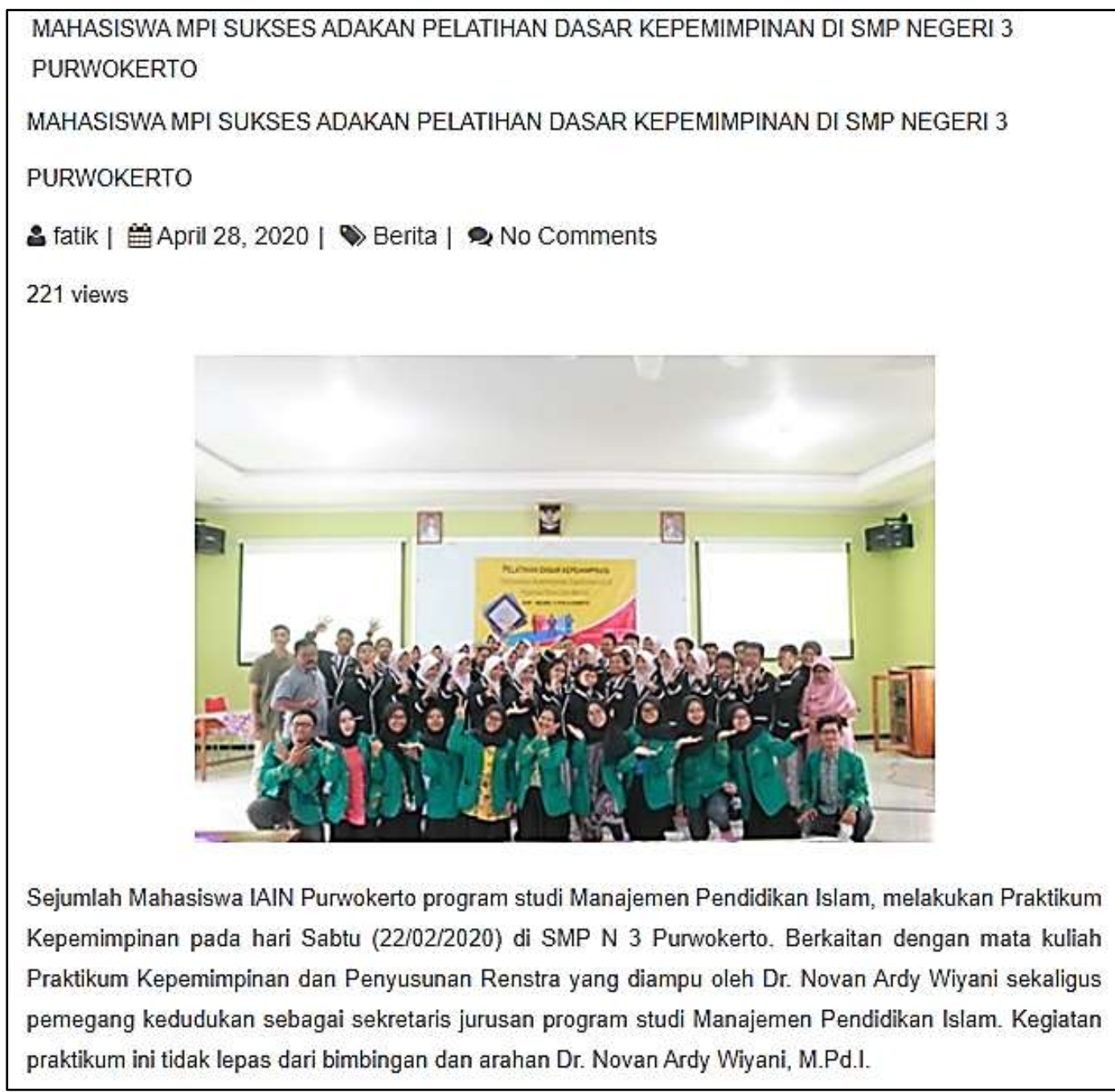

(sumber: http://ftik.iainpurwokerto.ac.id/, 2020)

\section{Gambar 2. Berita Kegiatan Praktikum Kepemimpinan dan Renstra Berbasis Pengabdian kepada Masyarakat}

Tahap keempat adalah pengawasan kegiatan praktikum kepemimpinan dan renstra berbasis pengabdian kepada masyarakat. Kegiatan pengawasan ini dilakukan oleh penulis sebagai wujud tanggungjawab penulis sebagai dosen pengampu sekaligus pembina (Purwanto, 2017). Pengawasan pada kegiatan pengabdian masyarakat ini dilakukan melalui 2 bentuk. Pertama, pengawasan dalam bentuk pelaksanaan monitoring. Penulis sebagai dosen pengampu mata kuliah praktikum kepemimpinan dan renstra melakukan kegiatan monitoring pada saat mahasiswa menyelenggarakan kegiatan diklat kepemimpinan. Kegiatan monitoring ini dilaksanakan dalam bentuk kunjungan lapangan. Pada kunjungan lapangan tersebut 
penulis bukan sekedar menilai kemampuan mahasiswa dalam menyelenggarakan diklat kepemimpinan, tetapi juga memberikan pendampingan dan motivasi dan arahan kepada mahasiswa ketika melaksanakan diklat kepemimpinan. Namun pada dasarnya kegiatan monitoring dilakukan sebagai upaya untuk mengendalikan (control) pelaksanaan kegiatan agar jalannya pelaksanaan kegiatan benar-benar mengarah pada pencapaian tujuan pengabdian kepada masyarakat yang telah ditentukan (Pidarta, 1999).

Kedua, pengawasan dalam bentuk studi dokumen. Pengawasan ini dilakukan dengan melakukan telaah dan penilaian terhadap laporan kegiatan diklat kepemimpinan yang disusun mahasiswa (Sulistyorini, 2009). Studi dokumen dilakukan karena adanya keterbatasan waktu pada saat penulis melakukan kegiatan monitoring. Ditemukan mahasiswa yang menyelenggarakan kegiatan diklat kepemimpinan dalam waktu yang bersamaan pada beberapa sekolah dan madrasah. Namun hal itu tidak menjadi masalah yang besar karena lokasi diklat kepemimpinan tidak saling berjauhan.

Ada tiga faktor pendukung dalam pelaksanaan kegiatan praktikum kepemimpinan dan renstra berbasis pengabdian masyarakat. Pertama, adanya MoU antara pihak FTIK IAIN Purwokerto dengan sekolah dan madrasah yang dituju untuk melaksanakan pengadian kepada masyarakat memudahkan mahasiswa untuk bernegosiasi dengan pihak sekolah dan madrasah dalam hal penentuan waktu, tempat, dan peserta kegiatan. Kedua, keberadaaan WA Group memudahkaan penulis untuk melakukan koordinasi dan komunikasi dengan mahasiswa peserta kegiatan untuk kepentingan penyelenggaraan diklat kepemimpinan. Ketiga, mahasiswa sudah memiliki bekal yang cukup untuk menjadi tutor diklat kepemimpinan dari hasil perkuliahan kepemimpinan, perkuliahan administrasi pendidikan, dan perkuliahan komunikasi organisasi.

Kemudian ada tiga faktor penghambat dalam pelaksanaan kegiatan praktikum kepemimpinan dan renstra berbasis pengabdian masyarakat. Pertama, keterbatasan anggaran, di mana anggaran kegiatan ditanggung secara kolektif antara penulis sebagai dosen pengampu dan mahasiswa. Kedua, adanya kegiatan diklat kepemimpinan yang dilaksanakan secara bersamaan pada beberapa sekolah dan madrasah sehingga sedikit menyulitkan jalannya kegiatan monitoring. Ketiga, penyusunan laporan kegiatan agak terhambat karena pengaruh pandemi covid-19.

\section{KESIMPULAN DAN SARAN}

Kegiatan praktikum kepemimpinan dan renstra berbasis pengabdian kepada masyarakat merupakan salah satu terobosan yang dilakukan oleh penulis sebagai dosen pengampu untuk 
menjadikan kegiatan tri dharma perguruan tinggi dapat dilaksanakan secara terintegrasi. Kegiatan pendidikan dan pengajaran (perkuliahan) dilaksanakan secara bersamaan dengan kegiatan pengabdian kepada masyarakat. Agar hal itu bisa dilakukan dengan baik maka kegiatan praktikum kepemimpinan dan renstra berbasis pengabdian masyarakat perlu dikelola dengan baik, dengan melakukan empat tahap kegiatan.

Pertama, tahap perencanaan kegiatan praktikum kepemimpinan dan renstra berbasis pengabdian kepada masyarakat. Pada tahap ini dilakukan perumusan tujuan, penyusunan RPS yang mengarah pada suksesi pelaksanaan kegiatan praktikum serta sosialisasi kegiatan praktikum kepemimpinan dan renstra berbasis pengabdian kepada masyarakat. Kedua, tahap pengorganisasian kegiatan praktikum kepemimpinan dan renstra berbasis pengabdian kepada masyarakat. Pada tahap ini penulis melakukan koordinasi dengan staf, kabag akademik, wakil dekan III, ketua jurusan MPI, dan dekan FTIK IAIN Purwokerto. Koordinasi tersebut pada dasarnya dilakukan untuk mendapatkan bahan dalam penentuan lokasi kegiatan pengabdian serta untuk mendapatkan dukungan secara legal-formal dari berbagai stakeholders.

Ketiga, tahap pelaksanaan kegiatan praktikum kepemimpinan dan renstra berbasis pengabdian kepada masyarakat. Pada tahap ini dilakukan sosialisasi tempat kegiatan, membuat TOR kegiatan, melakukan kunjungan ke sekolah dan madrasah tempat kegiatan, melaksanakan diklat kepemimpinan, dan membuat serta mempublikasikan teks berita kegiatan di website FTIK. Keempat, tahap pengawasan kegiatan praktikum kepemimpinan dan renstra berbasis pengabdian kepada masyarakat. Ada dua bentuk kegiatan pengawasan yang dilakukan, yaitu monitoring dengan melakukan kunjungan lapangan dan studi dokumentasi terhadap laporan kegiatan yang disusun oleh mahasiswa.

Berdasarkan hasil dan hambatan dalam pelaksanaan kegiatan maka ada tiga saran yang penulis ajukan. Pertama, dekan FTIK IAIN Purwokerto sebaiknya memberikan masukan dan dukungan moral maupun material pada dosen agar mampu menyelenggarakan kegiatan perkuliahan berbasis pengabdian kepada masyarakat. Kedua, ketua jurusan MPI agar memberikan pendampingan kepada dosen yang memiliki inovasi untuk melaksanakan kegiatan perkuliahan berbasis pengabdian kepada masyarakat. Ketiga, kepala sekolah ataupun kepala madrasah hendaknya melakukan tindaklanjut kegiatan terhadap MoU yang telah dibuat oleh pihaknya dengan pihak FTIK IAIN Purwokerto.

\section{UCAPAN TERIMA KASIH}

Penulis ucapakan terima kasih kepada pihak-pihak yang telah membantu dalam mensukseskan kegiatan praktikum kepemimpinan dan renstra berbasis pengabdian kepada 
masyarakat, seperti dekan FTIK, wadek III, ketua jurusan MPI, kabag akademik, dan para mahasiswa MPI semester 6. Ucapan terima kasih juga penulis haturkan untuk kepala sekolah dan kepala madrasah pada (1) MTs al-Hidayah Karangsuci Purwokerto; (2) MTs al-Ittihad Ma'arif NU Purwokerto Barat; (3) MTs al-Masruriyah Kebumen Baturraden; (4) MTs Ma'arif NU 1 Kedungbanteng; (5) SMP Negeri 3 Purwokerto; (6) MA al-Ikhsan Beji Kedungbanteng; (7) SMA Diponegoro Purwokerto; dan (8) SMK Ma’arif NU Karanglewas.

\section{DAFTAR PUSTAKA}

Dedy Mulyasana. (2015). Pendidikan Bermutu dan Berdaya Saing. Rosda.

Efferi, A. (2019). Manajamen Strategik Rekrutmen Peserta Didik Baru Di MA Nahdlotul Muslimin Undaan Kudus. Edukasia: Jurnal Penelitian Pendidikan Islam, 14(1), 25. https://doi.org/10.21043/edukasia.v14i1.4844

Erwin Widiasworo. (2017). Inovasi Pembelajaran Berbasis Life Skill dan Entrepreneurship. ArRuzz Media.

Hikmah, N. (2014). Manajemen Kurikulum Bidang Penelitian Di STAIN Kudus. Edukasia: Jurnal Penelitian Pendidikan Islam, 9(1). https://doi.org/10.21043/edukasia. v9i1.770

Khairiah, K., \& Sirajuddin, S. (2019). The Effects of University Leadership Management: Efforts to Improve the Education Quality of State Institute for Islamic Studies (IAIN) of Bengkulu. Jurnal Pendidikan Islam, 7(2), 239-266. https://doi.org/10.14421/jpi.2018.72.239-266

M. Ngalim Purwanto. (2017). Administrasi dan Supervisi Pendidikan. Rosda.

Machali, I. (2019). Managing Quality of Learning in Islamic Schools: An Analysis of Contributing Factors for Learning Toward Quality Improvement in Private Islamic Senior High Schools in Yogyakarta. Jurnal Pendidikan Islam, 7(2), 317-335. https://doi.org/10.14421/jpi.2018. 72.317-335

Made Pidarta. (1999). Pemikiran tentang Supervisi Pendidikan. Bumi Aksara.

Maslahah, A. U. (2018). PENERAPAN KURIKULUM MENGACU KKNI DAN IMPLIKASINYA TERHADAP KUALITAS PENDIDIKAN DI PTKIN. Edukasia: Jurnal Penelitian Pendidikan Islam, 13(1). https://doi.org/10.21043/edukasia.v13i1.5717 Muh.Hizbul Muflihin. (2015). Administrasi Pendidikan. Gema Nusa.

Muhtifah, L., \& Muskania, R. T. (2019). The Design on Quality System Model of FTIK IAIN Pontianak in SNPT 2015 and QMS ISO 9001:2015. Jurnal Pendidikan Islam, 7(2), 383404. https://doi.org/10.14421/jpi.2018.72.383-404 
Munadi, M., Ernawati, F., \& Hakiman, H. (2019). The Reality of Knowledge Management in Islamic Higher Education. Jurnal Pendidikan Islam, 7(2), 225-237. https://doi.org/ 10.14421/jpi.2018.72.225-237

Muslih, M. (2018). Upaya Pengembangan Kurikulum Prodi S.2 Manajemen Pendidikan Islam (MPI) UIN Walisongo Semarang. Nadwa, 12(1), 155. https://doi.org/10.21580/nw. 2018.12.1.2466

Rahmi, S. (2019). Headmaster's Leadership in Solving Problems at Islamic Elementary School (SDI) Hikmatul Fadhillah Medan. Jurnal Pendidikan Islam, 7(2), 267-280. https://doi.org/ 10.14421/jpi.2018.72.267-280

Rismi Somad dan Donni Juni Priansa. (2014). Manajemen Komunikasi: Mengembangkan Bisnis Berorientasi Pelanggan. Alfabeta.

Sadiyah, H., Shofawi, M. A., \& Fatmawati, E. (2019). Manajemen Program Pendidikan Leadership untuk Siswa di Sekolah Alam Banyubelik Kedungbanteng Banyumas. Tarbawi: Jurnal Keilmuan Manajemen Pendidikan, 5(02), 251. https://doi.org/10.32678/ tarbawi.v5i02.2096

Sugeng Lustyo Prabowo. (2009). Implementasi Sistem Manajemen Mutu ISO 9001: 2008 di Perguruan Tinggi. UIN Maliki Press.

Sulistyorini. (2009). Evaluasi Pendidikan dalam Meningkatkan Mutu Pendidikan. Teras.

Tukiran Tanireja dan M. Yudhie Haryono. (2014). Pemimpin Berkarakter Pancasila. Alfabeta.

Wahjosumidjo. (2011). Kepemimpinan Kepala Sekolah: Tinjauan Teoritik dan Permasalahannya. Rajawali Press.

Widodo, S. A., Setiyawan, A., \& Zahida, A. (2019). Foreign Language Learning Management for World Class University Ranking (Comparative Study between State Islamic University (UIN) Sunan Kalijaga Yogyakarta and the University of Malaya (UM) Malaysia). Jurnal Pendidikan Islam, 7(2), 337-359. https://doi.org/10.14421/jpi.2018.72.337-359

Willy Susilo. (2018). Strategi Menegakkan Mutu Pendidikan Tinggi Berbasis KKNI. Andi. 